\title{
Learning Multimodality through Genre-Based Multimodal Texts Analysis: Listening to Students' Voices
}

\author{
Soni Tantan Tandiana, ${ }^{1 *}$ Fuad Abdullah, ${ }^{2}$ Yuyus Saputra ${ }^{3}$ \\ 1,2,3English Education Department, Siliwangi University, Tasikmalaya, West Java - Indonesia
}

\begin{abstract}
Recently, multimodality has Has attracted the attention of researchers, notably in the educational milieu. However, only a few studies reported on the way students perceived the use of Genre-Based Multimodal Texts Analysis (GBMTA) for teaching multimodality. After addressing the gap, this study focuses on students' perceptions on the use of GBMTA in multimodality teaching in higher education. Sixty-nine students were involved in the study. Each of the students produced one journal through three meetings. The journals were then collected for document analysis and thematic analysis (Braun \& Clarke, 2006). The findings reveal that the students perceived GBMTA as facilitating them in the building of multimodal discourse analysis, challenges and solutions of comprehending multimodal teaching materials, planning better learning strategies in the future, engagement on multimodal learning issues, and multimodal text analysis practices. This study contributes to multimodality teaching or multimodal discourse analysis within genre-based learning.
\end{abstract}

Article Information

Received 04 July 2020

Accepted 24 July 2020

Published Oct 15, 2020

Keywords: Genre-Based Multimodal Texts Analysis (GBMTA); higher education; learning multimodality; students' perceptions

\section{Introduction}

Recent years have seen increasing interests in multimodality (Dallyono \& Sukyadi, 2019; Jewitt, 2005; Kress, 2009; Lim, 2017; O'Halloran, Tan, Smith, \& Podlasov, 2010; Oostendorp, 2015; Parlindungan, Rifai, \& Safriani, 2018; Poulsen \& Kvåle, 2018). It aligns with the development of Information Communication and Technology (often abbreviated as ICT). In this digital era, communication tends to occur in a visual or pictorial turn (Jewitt, 2012).

*Corresponding Author: Soni Tantan Tandiana (sonitantantandiana@gmail.com) Jl. Siliwangi No.24, Kahuripan, Kec. Tawang, Tasikmalaya, Jawa Barat 46115
Concerning this, Hyland (2009) argues that visuals encompass three major metafunctions (e.g. ideational, interpersonal, and textual metafunctions) viewed from Systemic Functional Linguistics (SFL), which can supply information, assist in the construction of dialogues, and inspire audiences. Besides, multimodality deals with diverse communication modes, their connections, and integrated processes on communication and representation (Jewitt, 2009; Kress, 2010; Kress \& van Leuween, 2001; O'Halloran \& Smith, 2011). Taylor and Leung (2019) propose that reading and writing are not isolated skills, but they are closely intertwined with with additional representational modes. With these in mind, contemporary educational 
objectives and requirements have been directed to reframing classroom language teaching practices which initially employed traditional view (e.g. reading and writing) to multimodal one (e.g. multimodal literacies) (Taylor \& Leung, 2019).

Multimodality refers to modes used in meaning-making practices, such as linguistic, visual, audio, gestural, and spatial modes (Jewitt, 2009; New London Group, 1996). This concept has emerged to revolutionize the previous concepts considering that communication and representation run monomodally and depend on language as the only tool of meaning-making (Kress, Jewitt, Ogborn, \& Tsatsarelis, 2001). Because learning practices are commonly performed multimodally, teachers are expected to be able to employ various pedagogical approaches involving the combination of semiotic resources (Victor, 2011). By doing so, they can facilitate their students' learning to understand teaching-learning materials effectively since multimodality-based teaching involves various sensory modalities, such as visual, auditory, tactile, olfactory, gustatory and kinaesthetic modes.

Multimodality is constructed from a social semiotic theory emphasizing power, representation, and communication (Kress \& van Leuween, 2001). The notion of modes is ascribed as a social and cultural resource to make meanings (Stec, 2019). For instance, modes are manifested in writing, images, gestures, and 3D objects. In addition, modes are utilized reciprocally with semiotic resources (e.g., modes in a cultural history) (Kress \& van Leuween, 2001). Grounded on this notion, multimodal pedagogy can assist students in literacy learning, which changes dynamically based on semiotics orientation, diverse text types, technologies, and meaning-making alternatives in this era (Ajayi, 2009).

The advancement of information, communication, and technologies (ICT) has shifted the paradigm of literacy learning. Kress (2003) posits that literacy in the new media age embraces human, cognitive, affective, cultural, and physical involvements in knowledge construction. In other words, literacy is no longer viewed as an alphabetic literacy emphasizing on the ability to read and write (Kress, 2003; F. V. Lim, 2018). Rather, it goes beyond the previous concept of communication, that is monomodal literacy (Kress, 2003; F. V. Lim, 2018; New London Group, 1996). Hence, multimodal literacy is regarded as crucial.

Multimodal literacy (Damayanti \& Febrianti, 2020; Kress, 2003; F. V. Lim, 2018; New London Group, 1996) or Multimodal Communicative Competence (MCC) (Royce, 2007) is the capacity to comprehend integrated communicative modes to make meanings. Similarly, Jewitt (2009) labels it as a "multimodal turn" in which language is combined with other semiotic resources (e.g., image, music, gesture, architecture, etc.) to make meanings multimodally. Equally, Christie (2002) considers that language cannot be understood only from other semiotic resources since people's semiosis is constructed through the integration of semiotic resources. Introducing multimodal literacy to students enables them to cultivate their capacity to analyze multimodal texts critically, to articulate their conceptual knowledge to create successful multimodal texts, and to communicate multimodally (F. V. Lim, 2018).

In Systemic Functional Linguistic tradition (hereafter, SFL), genre refers to "a staged goal- 
oriented social process" (Martin, 2009, p. 10). In this case, language is portrayed as language use in diverse social contexts (Martin, 1992; Martin \& Rose, 2007, 2008). This is different from the concept of genre in English for Specific Purposes (ESP) approach which focuses on rhetorical structures (e.g., structure, style, content and intended audiences) of a text to reach communicative purposes in communicative events (Swales, 1990). Meanwhile, the New Rhetoric School approach views genre as sociocontextual elements built from actions and comprehension of those elements (sociocontextual elements) varying consistently (Paltridge, 1997). Anchored in these ideas, genre is delineated as text types constructed from systematic, functional, communicative, and rhetorical elements to achieve particular communicative purposes.

Pedagogically speaking, genre plays predominant roles in language pedagogy. This is emphasized by much research focusing on how it is used in language teaching and learning (e.g., Feez, 1998; Gunawan, 2018; F. V. Lim, 2018; Rose \& Martin, 2012; Rothery, 1996). One of the most frequently employed teaching approaches to genre is the Genre-Based Approach (henceforth, GBA) (Emilia, 2005; Feez, 1998; Rose \& Martin, 2012; Rothery, 1996). Feez (1998) argues that GBA enables the students to understand and construct genres in heterogeneous fields and grades. Further, it helps students think critically about knowledge and practices of social semiosis, which construct the knowledge.

Technically, GBA consists of some stages, which are Building Knowledge of the Field (BKoF), Modelling of the Text (MoT), Joint Construction of the Text (JCOT), Independent Construction of the Text (ICOT) and Linking of Related Texts (LoRT) (Rose \& Martin, 2012; Rothery, 1996).
However, the present study puts an emphasis on how GBA is tailored for multimodality learning through multimodal text analysis. In other words, GBA is modified to be Genre-Based Multimodal Texts Analysis (henceforward, GBMTA) encompassing relevant stages of GBA, such as Building Knowledge of Genre-Based Multimodal Text Analysis, Modelling of Genre-Based Multimodal Text Analysis, Joint Genre-Based Multimodal Text Analysis, Independent GenreBased Multimodal Text Analysis and Linking of Related Texts (Abdullah, Tandiana, Komara, in press; Feez, 1998; Rose \& Martin, 2012; Rothery, 1996). In the first stage, Building Knowledge of Genre-Based Multimodal Text Analysis, the students are directed to familiarise themselves with various multimodal texts, and their analytical tools (e.g. poster is analyzed with compositional meaning analytical framework). In the second stage, Modelling of Genre-Based Multimodal Text Analysis, they are provided with a model of multimodal text analysis and their possible analytical tools practically (e.g., the students observed and tried to analyze a multimodal text as modeled by the presenters). In the third stage, Joint Genre-Based Multimodal Text Analysis, they are scaffolded to engage in analyzing practices collaboratively (e.g., the students were guided to select a multimodal text and analyze it collaboratively with their classmates). In the fourth stage, Independent Genre-Based Multimodal Text Analysis, they are given opportunities to individually develop their conceptual and practical knowledge on how multimodal text is analyzed with a particular analytical tool (e.g. the students are given a task to analyze a multimodal text individually and disseminate their analysis results in the upcoming meeting). In the final stage, Linking of Related Texts, the students are encouraged to review and relate their analysis results and interpretation to 
other resources to triangulate what they found from the existing or previous ones (e.g. the students were suggested to compare, relate and associate their analysis results with the existing empirical findings from previous studies and theories). In short, these stages are aimed at facilitating the students to be able to systematically analyse multimodal texts.

In accordance with the valuable contributions of multimodality to language pedagogy, many researchers have conducted empirical investigations on various issues, such as teaching multimodal texts analysis to junior high school students (Ajayi, 2009), multimodal analysis for critical thinking (MACT) (O'Halloran et al., 2015), multimodal communicative competence (MCC) (Coccetta, 2018), systemic functional approach to teaching multimodal literacy (F. V. Lim, 2018), multimodal literacy and design of learning (Nouri, 2019) and semiotic resources constructed in a picture book for children (Damayanti \& Febrianti, 2020). However, a few studies focused on scrutinizing multimodality from genre-based pedagogy (e.g., Molle \& Prior, 2008), the one in Indonesian context only focused on multimodal English text (e.g., recount text) teaching at senior high schools (Rahmadhani, 2018; Suherdi, 2015). Even none of the studies provide insights into students' perceptions on a genre-based approach to multimodality learning. Grounded on the critical viewpoint of students' perceptions on the employment of Genre-Based Multimodal Text Analysis (GBMTA), this study explores the students' perceptions on the implementation of GBMTA in multimodality teaching.

\section{Method}

By employing a descriptive case study design, this research aims at exploring students' perceptions on the implementation of genrebased multimodal texts analysis in multimodality teaching. A descriptive case study was used to investigate an intervention, a phenomenon, or an actual context where it takes place (Baxter \& Jack, 2008; Yin, 2003). This design was used because it enables the researcher to get involved in contextual conditions and the existing phenomenon (Abdullah \& Lulita, 2018; Andriani \& Abdullah, 2017; Baxter \& Jack, 2008).

The present study was conducted at an English Education Department (EED) of a state university in Tasikmalaya, West Java, Indonesia. It involved 32 students ( $N=8$ males and 24 females) as research participants. They are between 19-22 years old. All of them can communicate in Basa Sunda (L1), Bahasa Indonesia (L2), and English (FL). Several considerations for selecting the research setting and recruiting the participants were the presence of Grammar in Multimodal Discourse (hereafter, GiMD), the accessibility of data sources, implementing institutional policies, the Genre-Based Multimodal Texts Analysis implementation (GBMTA), the students' consent to participate in the research, and the underresearched issue of multimodality or multimodal discourse analysis, especially in Indonesian EFL context. The research data were obtained from 288 students' reflective journals in one of the GiMD classes. Those reflective journals were collected from the second to the ninth meeting because, in such meetings, the implementation of GBMTA in classroom learning activities is considered effective, beyond the middle test, final project consultations, and final test. The students were instructed to write in a reflective journal based on a guiding template comple- 
mented with given questions to reveal their learning experiences (what did I learnt in the class?), challenges (what challenges did I encounter during learning activities?), problemsolving skills (what did I do to overcome those difficulties?) and future learning plans (what should I do next for my better learning?). The reflective journals were collected collectively via email by a representative of the class (leader of the class).

The research data were analyzed thematically (Braun \& Clarke, 2006). Thematic analysis was performed to analyze, manage, delineate, and inform themes reflected in a data set (Braun \& Clarke, 2006). The main advantages underlying the use of this analytical tool were its flexibility, particularity, and contextuality, supporting the researcher to fine-tune the existing data with the empirical needs (Braun \& Clarke, 2006). More practically, the analytical procedure encompassed six major steps, which were familiarising with the data, generating initial codes, searching for themes, reviewing themes, defining and naming themes, and producing the report (Braun \& Clarke, 2006).

\section{Findings and Discussion}

\section{Knowledge building of Multimodal Discourse Analysis}

When learning multimodality in GiMD class, the teacher applied GBMTA as a teaching technique. One of the steps in such a technique is Building Knowledge of Genre-Based Multimodal Text Analysis. In this step, the students were guided to comprehend multi-modal texts and genre-based multimodal text analysis. In particular, they learned how meanings are conveyed through various communication modes, such as visual, auditory, tactile, olfactory, gustatory, and kinaesthetic modes (Kress \& van Leuween, 2006; O'Halloran \& Smith, 2011). More specific information is elaborated in excerpt \#1 as follows:

\section{Excerpt \#1}

I learned about the concept of Discourse, Multimodal Discourse Analysis, focuses on MDA which comprises semiotic resource, intersemiosis and resemiotization, challenges on conducting MDA, reasons of paradigmatic shift from single linguistic resource to multimodal ones, approaches to MDA, theoretical and analytical issues on MDA, and doing some simple analysis on some pictures based on our prior knowledge. ( $3^{\text {rd }}$ meeting reflective journal of participant \#8).

As the excerpt indicates, participant \#8 learned conceptual knowledge of discourse, notably Multimodal Discourse Analysis. It is reflected by his statement claiming that he learned semiotic resources, intersemiosis and resemiotization, challenges of conducting MDA, paradigmatic shift from monomodality and practicing how to analyze pictures based on their prior knowledge. Consistent with this, multimodal analytical procedures put a heavy emphasis on textual and pictorial modes as the focus of investigation (V. F. Lim, 2017). In short, GBMTA enables the students to build their knowledge of Multimodal Discourse Analysis (MDA).

\section{Challenges and Solutions of Comprehending Multimodal Teaching Materials}

Another finding reveals the students' challenges and solutions while comprehending one of the multimodal teaching materials (e.g., Multimodal Social Semiotics on a university website, interactive meaning etc.). As an illustration, participant \#23 acknowledged that she was still confused about the representation 
of network viewer as an analysed element in website analysis process through Multimodal Social Semiotics analytical lens (Kress, 2010; Michelson \& Valencia, 2016).

\section{Excerpt \#2}

I am still confused about the representation and network viewer and also I'm a bit confused about how our interpretation is spoken when we did not find any sources as our background knowledge to interpret a thing which pictures, sounds, or gestures (2nd meeting reflective journal of participant \#23).

In addition to the challenges of understanding an issue in multimodal teaching materials, participant \#23 encountered another challenge when trying to interpret spoken discourse since she could not locate any supporting and relevant sources "I'm a bit confuse how our interpretation is spoken when we did not find any sources." Likewise, she assumed that the challenges to interpret meanings and discourses represented in such a website derived from her inadequate knowledge of analyzed pictures, sounds, and gestures.

To resolve her challenges, participant \#23 learned from her peer (e.g., noticing classroom presentation of participant \#18) disseminating visual analysis of a university website. In addition, she was able to identify the forms and functions of Multimodal Social Semiotics (MSS) proposed by Kress (2010) as an analytical tool to analyze a website. The tool consists of four major components, namely rhetor (the initiating agent of the meaning-making process), design (decisions about genre, mode, discourse, and medium which are made), ground (a message) that was designed by an institution), and interpreter (the website user/ interpreter who engage with a ground that was designed by an institution/rhetor) (Kress, 2010; Michelson \&
Valencia, 2016). It is exemplified in the following excerpt:

\section{Excerpt \#3}

On Wednesday, 13 March 2019, I've learned about website analysis through presentation from participant \#18 and friends about visual analysis on university website. On the article they have been presented, the researcher used case study as their method to analyse the visual of website to find four components of Kress' Model (rhetor, design, ground, and interpreter) (2nd meeting reflective journal of participant \#23).

Consequently, she understood what MSS is, why using it to analyze a website and how to deploy it practically after learning from her peer. Given these facts, Modelling of Genre-Based Multimodal Text Analysis (Abdullah et al., in press; Feez, 1998) as a stage of GBMTA contributes to the students' understanding of multimodal teaching materials and collaborative learning.

\section{Planned better learning strategies in the future}

Once they reflected on their learning experiences in GiMD course, they realized that they should be able to reach better learning outcomes for each meeting. Participant \#5 planned to allocate more free time to learn multimodal teaching materials (e.g., learning how to analyse pictures). It is due to her confusion of comprehending multimodal teaching materials, as reflected in excerpt \#4.

\section{Excerpt \#4}

I should have free time and try to learn more about how to analyze the picture, because I'm still confused (3rd meeting reflective journal of participant \#5)

Another future learning plan was mentioned by participant \#17, who was aware that she was 
a passive student in the class. As a result, she planned to be more active during learning activities in GiMD course as denoted by what she expressed "I have to be an active student in the lecturer's class." Besides, she tried to motivate herself to learn better.

\section{Excerpt \#5}

Perhaps, especially for me. I have to be an active student in the lecturer's class in order to I can motivate myself to be better (3rd meeting reflective journal of participant \#17)

This shows that participant \#17 is able to play her role as an aware and motivated student by possessing a better learning plan.

In a similar vein, participant \#27 has planned to attain better learning outcomes in the upcoming classroom meeting. Initially, she realized that she had not read the teaching materials extensively even though the teacher had provided a plenty of reading materials (e.g., journals, books, chapter books, etc.) to widen their insight and deepen their knowledge on multimodal teaching materials. Further, since in the next meeting, she and her group had to present a multimodal teaching material, she did some preparation activities, such as searching for relevant resources to support her materials for classroom presentation as displayed in the excerpt \#6.

\section{Excerpt \#6}

I think for the next for my better learning, I must read the journal from the lecturer and searching to the internet about the materials for next week because it's time to my group presentation to give the materials (7th meeting reflective journal of participant \#27)

Overall, although they (participant \#5, 17 \& 27) faced miscellaneous challenges when taking part in GiMD learning activities, they could overcome such challenges by reflecting on their learning weaknesses and improve their learning performance through their own planned learning strategies. It is relevant to the notion of Macken-Horarik (2002) that Systemic Functional Linguistics Genre Pedagogy (henceforth, SFL GP) supports students in accessing educational discourses, familiarising and criticizing with various genres needed for their academic, professional, and social purposes.

\section{Engagement on multimodal learning issues}

The students' engagement on multimodal issues has become one of the central findings of this study because it represents their perceptions on learning issues offered in GiMD course. To exemplify, participant \#1 stated that she learned poster analysis discussing theoretical and practical underpinnings of how a poster is analyzed based on a particular analytical framework (e.g., compositional analytical framework). In particular, she shared her experience when joining GBMTA on posters of an Irish political party (Fianna Fail). They learned the analytical components of the compositional analytical framework, such as information value, framing, and salience (Kress \& van Leuween, 2006). Information value refers to the positioning of elements providing particular informational values attributed to sundry image zones (e.g., left and right, top and bottom, center, and margin). Framing is associated with the elements created to grab the people's attention at various levels and manifested in the positioning of foreground, background, relative size, contrasts in tonal value (e.g., colors), diverse types of sharpness and so forth. Salience constitutes the existence or non-existence of framing tools uniting or separating image 
elements indicating whether or not they are part of a particular mode (Kress \& van Leuween, 2006). These compositional meaning elements become a prescribed guidance for the students to engage in the analysis of multimodal texts (e.g., poster), especially for locating compositional meanings (Lirola, 2016).

Technically, information value encompasses margins, positioning, and direction of a multimodal text. Salience is commonly manifested in colors, size, sharpness, and fonts. Framing covers connected or disconnected associations between writing, background, and foreground. Grounded in such an analytical framework (compositional meaning analytical framework), the students were engaged in interactive teaching and learning activities. Gunawan (2014, p. 37) adds that "if teachers teach students to construct meanings in a text to engage readers, they focus on how the authors commonly use language to engage readers".

Participant \#1 expressed her perceptions on deploying compositional analytical framework to a poster (e.g., political poster), such as understanding the strategies of political campaigns of Fianna Fail existing in a journal given by the teacher, identifying how to practically analyze it, and sharing their understandings to classmates to have further discussions. Additionally, she and her learning group sought for another poster relevant to their field, that is English Education. Once they found a poster (e.g., educational poster in Nepal), they analyzed it collaboratively. Then, they disseminated the results of the analysis to their classmates. These are denoted in the subsequent excerpt:

\section{Excerpt \#7}

This week I have learned about poster analysis. Some things that must be analyzed are compositional meaning where they are divided 3. The first, information value including margins, positioning, and direction. The second salience includes colors, size, sharpness, and fonts. And the third is framing where there are connected and unconnected between writing and background. Here I study several posters of political campaigns from Fianna Fail. After that, I tried to analyze one of the educational posters. The poster I chose was an educational poster in Nepal. This poster illustrates how education is in Nepal. In analyzing this poster, we worked in groups. We share several tasks with each of us so we can work (3rd meeting reflective journal of participant \#1)

Hence, GBMTA is regarded as facilitating the students to experience cognitive and behavioral engagement during GiMD learning activities.

\section{Multimodal text analysis practices}

The students learned multimodal knowledge not only theoretically but also practically. It is outlined in GBMTA learning activities containing the following elements Building Knowledge of Genre-Based Multimodal Text Analysis, Modelling of Genre-Based Multimodal Text Analysis, Joint Genre-Based Multimodal Text Analysis, Independent Genre-Based Multimodal Text Analysis, Linking of Related Texts (Abdullah et al., in press; Feez, 1998). However, this study does not discuss Linking to Related Texts due to its absence from the data analysis results. These activities are depicted in the following excerpt:

\section{Excerpt \#6}

In this meeting, I learnt about journal that explains how to analyze the political poster. The political poster designed to represent the leader of Fianna Fail party during the four general election campaigns that took place from 1997 to 2011. This discussion was presented by participant \#6's group and after that we try to analyze another poster that served by participant \#6's group. We try to 
analyze it based on the background of the poster maker, the picture that attach, the color of poster, the text and the space. And the last activity is the lecture gave us the assignment to analysis another educational poster (7th meeting reflective journal of participant \#20)

In this case, they learned theoretical knowledge in the first stage, namely Building Knowledge of Genre-Based Multimodal Text Analysis. As an example, participant \#20 learned theories for analyzing political posters from an article entitled Multimodal analysis of a sample of political posters in Ireland during and after the Celtic Tiger written by (Lirola, 2016). It discusses how compositional meaning is represented in Irish political posters involving an Irish republican political party (Fianna Fail) and its candidate to run in the Prime Minister election (Bertie Ahern). This is reflected by what participant \#20 mentioned "I learnt about journal that explains how to analyze the political poster. The political poster designed to represent the leader of Fianna Fail party during the four general election campaigns that took place from 1997 to 2011." This emphasizes that the students are equipped with sufficient theoretical knowledge about what a poster is, how to analyse it multimodally and interpret the compositional meanings represented in a multimodal text.

In Modelling of Genre-Based Multimodal Text Analysis, participant \#20 was given a model of analysis to familiarise herself with semiotic resources in a multimodal text (posters) and a particular analytical framework (e.g., compositional meaning analytical framework). Such an activity is reflected by her statement, that "this discussion was presented by participant \#6's group and after that we try to analyze another poster served by participant \#6's group." She mentioned that she was guided in observing a step-by-step analyzing process, describing the analysis results and interpretation as modeled by her classmates.

In Joint Genre-Based Multimodal Text Analysis, participant \#20 was required to work together with other students and start analyzing an educational poster collaboratively in the class. In practice, she portrayed that she collaboratively analyzed a poster as reflected by what she stated: "We try to analyze it based on the background of the poster maker, the picture attached, the color of poster, the text and the space." She further elaborated that she and her group specifically analysed an educational poster from the perspective of poster designers, poster colours and poster textual, pictorial, and spatial information. By doing this, participant \#20 was encouraged to have collaborative learning experiences which are beneficial for her, particularly to share her ideas and confirm her understanding on multimodal texts analysis.

Different from Joint Genre-Based Multimodal Text Analysis motivating the students to learn collaboratively, Independent Genre-Based Multimodal Text Analysis enables them to learn individually and autonomously. This is shown by the utterance of participant \#20 "And the last activity is the lecture gave us the assignment to analysis another educational poster. In this case, she was given the assignment to analyse another educational poster individually and submitted it to the teacher next week. Rose and Martin (2012, p. 7) contend that teaching "should be harmonized with students' experience, knowledge, and need". This type of activity can encourage the students to learn autonomously and identify their theoretical and 
practical knowledge of the learned teaching materials.

To sum up, GBMTA is seen as giving the students opportunities to learn multimodal teaching materials theoretically and practically.

\section{Conclusion}

This study focused on exploring students' perceptions on the implementation of GBMTA in multimodality teaching in higher education. The findings reveal that the students perceived how GBMTA helps them in the area of knowledge building of multimodal discourse analysis, challenges and solutions of comprehending multimodal teaching materials, planning better learning strategies in the future, engagement on multimodal learning issues, and multimodal text analysis practices. In other words, the students had positive perceptions on the use of GBMTA in multimodality teaching.

Pedagogically speaking, the students were guided to perform autonomous learning after experiencing scaffolded learning activities in GBMTA, such as building knowledge of genrebased multimodal text analysis, modeling of genre-based multimodal text analysis, joint genre-based multimodal text analysis, independent genre-based multimodal text analysis and linking related texts. With this in mind, they became aware of a paradigmatic shift in literacy learning (e.g., literacy is not only reading and writing but also multimodal literacy or multimodal communicative competence) due to their improved abilities to understand meanings from diverse multimodal texts.

While this study has provided findings which contribute to multimodality teaching (multimodal discourse analysis) and the implementation of GBMTA, it has some shortcomings.
First, the data might not provide a holistic/comprehensive insight into the research topic. Therefore, future studies should use multiple data collection techniques (e.g., document analysis, interview, or observation) for obtaining more credible and dependable data. Second, this study focused only on the students' perspective. Further research should include multiple perspectives from various participants, such as the perspectives of teachers, parents, policymakers or teaching materials designers, to attain intersubjectivity. In addition, this study involved homogeneous research participants, Indonesian EFL students majoring in English language education. Future research should involve other English language speakers, such as native English speakers, to capture more a comprehensive portrayal of English language learners globally (e.g., just considering English as a mother tongue, English as a second language, and English as a foreign language). Since the current study employed a descriptive case study design, it only investigated a phenomenon or the context of the investigated issue, such as the students' perceptions on the implementation of GBMTA in multimodality teaching in higher education. Future studies can use different research designs (e.g., exploratory or explanatory case study, ethnography, survey, critical discourse analysis etc.) to obtain deeper, wider, and more critical findings.

\section{References}

Abdullah, F., \& Lulita. (2018). Social actors in an intercultural communication classroom: A discursive lens of intercultural education. IJELT, 13(1), 31-51. 
Abdullah, F., Tandiana, S. T., \& Komara, U. (n.d.). Fostering multimodal communicative competence through genre-based multimodal texts analysis: Insight from an Indonesian higher education landscape. The Qualitative Report, 1-30.

Ajayi, L. (2009a). English as a second language learners' exploration of multimodal texts in a junior high school. Journal of Adolescent and Adult Literacy, 52(7), 585-595. https://doi.org/10.1598/JAAL.52.7.4

Ajayi, L. (2009b). English as a Second Language Learners' Exploration of Multimodal Texts in a Junior High School. Journal of Adolescent \& Adult Literacy, 52(7), 585-595. https://doi.org/10.1598/jaal.52.7.4

Andriani, A., \& Abdullah, F. (2017). Invigorating the EFL students in acquiring new linguistic knowledge: Language learning through projects. Proceedings of the 4th International Language and Language Teaching Conference, Yogyakarta, Nov 2017, 1-15.

Baxter, P., \& Jack, S. (2008). Qualitative case study methodology: Study design and implementation for novice researchers. The Qualitative Report, 13(4), 544-559.

Braun, V., \& Clarke, V. (2006). Using thematic analysis in psychology. Qualitative Research in Psychology, 3(2), 77-101. https://doi.org/ 10.1191/1478088706qp063oa

Christie, F. (2002). Classroom discourse analysis: $A$ functional perspective (R. Fawcett (ed.)). Continuum. https://doi.org/10.4324/9781315775630

Coccetta, F. (2018). Developing university students' multimodal communicative competence: Field research into multimodal text studies in English. System, 77, 19-27. https://doi.org/ 10.1016/j.system.2018.01.004
Dallyono, R., \& Sukyadi, D. (2019). An analysis of multimodal resources in environmental protection posters. Indonesian Journal of Applied Linguistics, 9(2), 472-479. https:// doi.org/10.17509/ijal.v9i2.20245

Damayanti, I. L., \& Febrianti, Y. (2020). Multimodal literacy: Unfolding reading path in children's picture book and its potential for EFL classrooms. Indonesian Journal of Applied Linguistics, 9(3), 616-627. https://doi.org/ 10.17509/ijal.v9i3.23212

Emilia, E. (2005). A critical genre based approach to teaching academic writing in a tertiary EFL context in Indonesia. [Unpublished doctoral thesis]. University of Melbourne, Australia.

Feez, S. (1998). Text-based Syllabus Design. National Centre for English Language Teaching and Research (NELTR), Macquarie University.

Gunawan, W. (2014). SFL in L2 writing teacher education: $A$ case study of an EFL pre-service teacher in conceptualizing grammar. [Unpublished doctoral thesis]. University of Massachusetts, USA.

Gunawan, W. (2018). Re-appropriation of ideational meanings through drawings: A case of 5year-old child experience in learning to mean. Indonesian Journal of Applied Linguistics, 8(2), 244-253. https://doi.org/ 10.17509/ijal.v8i2.13300

Hyland, K. (2009). Academic Discourse English in a Global Context (K. Hyland (ed.)). Continuum Discourse Series.

Jewitt, C. (2005). Classrooms and the design of pedagogic discourse: A multimodal approach. Culture and Psychology, 11(3), 309-320. https://doi.org/10.1177/1354067X05055519

Jewitt, C. (2009). The Routledge handbook of multimodal analysis (C. Jewitt (ed.)). Routledge. 
Jewitt, C. (2012). Technology, literacy, learning: A multimodal approach (C. Jewitt (ed.)). Routledge.

Kress, G. (2003). Literacy in The New Media Age (D. Barton (ed.)). Routledge.

Kress, G. (2009). Multimodality: A Social Semiotic Approach to Contemporary Communication. Routledge.

Kress, G. (2010). Multimodality: A Social Semiotic Approach to Contemporary Communication. Taylor \& Francis.

Kress, G., Jewitt, C., Ogborn, J., \& Tsatsarelis, C. (2001). Multimodal teaching and learning: The rhetorics of the science classroom (C. N., Candlin, \& S. Sarangi (eds.)). Continuum.

Kress, G., \& van Leuween, T. (2001). Multimodal Discourse The Modes and Media of Contemporary Communication. Arnold.

Kress, G., \& van Leuween, T. (2006). Reading images: The grammar of visual design. Routledge.

Lim, F. V. (2018). Developing a systemic functional approach to teach multimodal literacy. Functional Linguistics, 5(13), 1-17. https://doi.org/10.1186/s40554-018-0066-8

Lim, V. F. (2017). Analysing the teachers' use of gestures in the classroom: A systemic functional multimodal discourse analysis approach. Social Semiotics, 1-29. https://doi.org/10.1080/10350330.2017.141 2168

Lirola, M. M. (2016). Multimodal analysis of a sample of political posters in Ireland during and after the Celtic Tiger. Revista Signos, 49(91), 245-267. https://doi.org/10.4067/S071809342016000200005
Macken-Horarik, M. (2002). Something to shoot for: a systemic functional approach to teaching genre in secondary school science. In A. M. Johns (Ed.), Genre in the classroom: multiple perspectives (pp. 17-42). Lawrence Erlbaum.

Martin, J. R. (1992). English text: System and structure. John Benjamins Publishing Company.

Martin, J. R. (2009). Genre and language learning: A social semiotic perspective. Linguistics and Education, 20(1), 10-21. https://doi.org/ 10.1016/j.linged.2009.01.003

Martin, J. R., \& Rose, D. (2007). Working with discourse: Meaning beyond the clause (2nd Ed.). Continuum.

Martin, J. R., \& Rose, D. (2008). Genre relations: Mapping culture. Equinox.

Michelson, K., \& Valencia, J. A. Á. (2016). Study abroad: Tourism or education? A multimodal social semiotic analysis of institutional discourses of a promotional website. Discourse and Communication, 1-22. https://doi.org/10.1177/175048131562389 3

Molle, D., \& Prior, P. (2008). Multimodal Genre Systems in EAP Writing Pedagogy: Reflecting on a Needs Analysis. TESOL Quarterly, 42(4), 541-566. https://doi.org/10.1002/j.15457249.2008.tb00148.x

New London Group. (1996). A pedagogy of multiliteracies: Designing social futures. Harvard Educational Review, 66(1), 60-92. https://doi.org/10.17763/haer.66.1.17370n 67v22j160u

Nouri, J. (2019). Students Multimodal Literacy and Design of Learning During Self-Studies in Higher Education. Technology, Knowledge 
and Learning, 24(4), 683-698. https://doi.org/10.1007/s10758-018-9360-5

O'Halloran, K. L., \& Smith, B. A. (2011). Multimodal studies: Exploring issues and domains (K. L. O'Halloran \& B. A. Smith (eds.)). Routledge.

O’Halloran, K. L., Tan, S., \& Marissa, K. L. E. (2015). Multimodal analysis for critical thinking. Learning, Media and Technology. https://doi.org/10.1080/17439884.2016.110 1003

O’Halloran, K. L., Tan, S., Smith, B. A., \& Podlasov, A. (2010). Challenges in designing digital interfaces for the study of multimodal phenomena. Information Design Journal, 18(1), 2-21. https://doi.org/10.1075/ idj.18.1.02hal

Oostendorp, M. (2015). The multimodal construction of the identity of politicians. Critical Discourse Studies, 12(1), 39-56. https://doi.org/10.1080/17405904.2014.962 066

Paltridge, B. (1997). Genre, frames and writing in research settings (A. H. Jucker (ed.)). John Benjamins Publishing Company. https://doi. org/10.2307/417450

Parlindungan, F., Rifai, I., \& Safriani, A. (2018). The representation of Indonesian cultural diversity in middle school English textbooks. Indonesian Journal of Applied Linguistics, 8(2), 289-302. https://doi.org/10.17509/ ijal.v8i2.13276

Poulsen, S. V., \& Kvåle, G. (2018). Studying social media as semiotic technology: a social semiotic multimodal framework. Social Semiotics, 28(5), 700-717. https://doi.org/ 10.1080/10350330.2018.1505689
Rahmadhani, A. P. (2018). Genre Based Approach to Teaching Multimodal Text. Curricula, 3(2). https://doi.org/10.22216/jcc.2018.v3i2.3571

Rose, D., \& Martin, J. R. (2012). Learning to write, reading to learn: Genre, knowledge, and pedagogy in the Sydney school. Equinox.

Rothery, J. (1996). Making changes: Developing educational linguistics. In R. Hasan \& G. Williams (Eds.), Literacy in society. Addison Wesley Longman Limited.

Stec, M. (2019). Identity and multimodality of cultural content in ELT coursebooks for Yls. The European Proceedings of Social \& Behavioural Sciences, 72, 274-288. https://doi.org/10.15405/epsbs.2019.11.25

Suherdi, D. (2015). Proceeding The 62 nd TEFLIN International Conference 2015. Multimodal Pedagogy in TEFLIN Contexts.

Swales, J. M. (1990). Genre analysis: English in academic and research settings (Cambridge applied linguistics) (1st Ed.). Cambridge University Press.

Taylor, S. V., \& Leung, C. B. (2019). Multimodal literacy and social interaction: Young children's literacy learning. Early Childhood Education Journal, 1-10. https://doi.org/ 10.1007/s10643-019-00974-0

Victor, L. F. (2011). A systemic functional multimodal discourse analysis approach to pedagogic discourse. [Unpublished doctoral thesis]. National University of Singapore, Singapore.

Yin, R. K. (2003). Case study research: Design and methods (3rd Ed.). SAGE Publications Inc. 
Soni Tantan Tandiana, Fuad Abdullah, Yuyus Saputra 